\title{
STRATEGI PENERAPAN TRI HITA KARANA PADA SMP NEGERI 5 SINGARAJA
}

\author{
I Nengah Dwi Endra Suanthara \\ STKIP Agama Hindu Singaraja \\ E-mail: inengahdwiendra123@gmail.com
}

\begin{abstract}
Abstrak
Penelitian ini bertujuan untuk: (1) mengetahui strategi Implementasi Tri Hita Karana di SMP Negeri 5 Singaraja, (2) mengetahui faktor-faktor yang menghambat Implementasi Tri Hita Karana di SMP Negeri 5 Singaraja, (3) Untuk mengetahui dampak Implementasi Tri Hita Karana di SMP Negeri 5 Singaraja. Rancangan yang digunakan dalam penelitian ini adalah penelitian deskriptif kualitatif. Objek Penelitian ini adalah Implementasi Tri Hita Karana yang melandasi SMP Negeri 5 Singara sesuai hak dan kewajiban masyarakat sekolah baik sebagai siswa, guru maupun penyelenggara administrasi pendidikan. Metode Pengumpulan datanya adalah metode wawancara, observasi, dan analisis dokumen. Data yang terkumpul dianalisis dengan menggunakan model analisis interaktif yang meliputi langkah-langkah (1) reduksi data (2) penyajian data (3) penyimpulan data atau verifikasi data. Hasil penelitian menunjukkan bahwa (1) Strategi Implementasi Tri Hita Karana di SMP Negeri 5 Singaraja telah dilaksanakan adalah: (a) Parhyangan, membangun Padmasana dan melaksanakan upacara keagamaan, dengan melakukan berbagai kegiatan diantaranya melaksanakan pembersihan pada bangunan-bangunan suci. (b) Pawongan, dilaksanakan rapat, menyusun kegiatan-kegiatan sekolah. (c) Palemahan, dilaksanakan pengeloalaan lingkungan sekolah seperti penanganan sampah pelastik dan penanaman pohon sebagai perindang sekolah pada lahan yang masih kosong. (2) Faktor-faktor yang menghambat Implementasi Tri Hita Karana di SMP Negeri 5 Singaraja adalah : (a) Kondisi Lingkungan Sekolah, (b) Keberadaan ruang kelas, (c) Kebutuhan dan harapan. (3) Dampaknya Implementasi Tri Hita Karana di SMP Negeri 5 Singaraja adalah : (a) Parhyangan, kondisi Padmasana cukup baik dan bersih, (b) Pawongan, adanya kecendrungan perubahan pada perilaku warga masyarakat sekolah, (c) Palemahan, Keadaan lingkungan yang asri, taman sekolah yang hijau, kesehatan siswa yang baik,serta prestasi-prestasi yang di capai menjadi lebih baik.
\end{abstract}

Kata Kunci: Implementasi, Tri Hita Karana

\begin{abstract}
This study aims to: (1) find out the implementation strategy of Tri Hita Karana in Singaraja State Junior High School 5, (2) find out the factors that hinder Tri Hita Karana Implementation in Singaraja Public Middle School 5, (3) To determine the impact of Tri Hita Karana Implementation in Singaraja 5 Public Middle School. The design used in this study is qualitative descriptive research. The object of this research is the implementation of Tri Hita Karana which underlies Singara 5 Public Middle School according to the rights and obligations of the school community both as students, teachers and administrators of educational administration. The data collection method is the method of interview, observation, and document analysis. The collected data was analyzed using an
\end{abstract}


interactive analysis model which included steps (1) data reduction (2) data presentation (3) data inference or data verification. The results of the study show that (1) the Implementation Strategy of Tri Hita Karana in Singaraja State Middle School 5 has been carried out: (a) Parhyangan, building Padmasana and carrying out religious ceremonies, by carrying out various activities such as carrying out cleaning on sacred buildings. (b) Pawongan, held meetings, compiled school activities. (c) Palemahan, the management of the school environment is carried out such as handling plastic waste and tree planting as school litters on vacant land. (2) Factors that hinder the implementation of Tri Hita Karana in Singaraja State Junior High School 5 are: (a) School Environment Conditions, (b) Classroom existence, (c) Needs and expectations. (3) The impact of the implementation of Tri Hita Karana in Singaraja State Junior High School 5 is: (a) Parhyangan, Padmasana conditions are quite good and clean, (b) Pawongan, there is a tendency to change the behavior of school community members, (c) Palemahan, Beautiful environment, green school parks, good student health, and accomplishments that are bettered.

Keywords: Implementation, Tri Hita Karana

\section{PENDAHULUAN}

Tri Hita Karana merupakan sikap hidup umat Hindu yang seimbang atau harmonis antar manusia dengan Tuhan, manusia dengan manusia dan manusia dengan lingkungan alam. Dalam mewujudkan hubungan harmonis seimbang tersebut memegang peran yang sangat penting: menjalin hubungan yang baik simbang harmonis dengan tuhan dilakukan melalui yakin dan bhakti kepada Tuhan. Hubungan baik antar sesama manusia dilakukan dengan saling percaya, menghargai, menolong satu sama lain dengan tulus iklas tanpa berharap balasan. Hubungan yang baik harmonis dapat memberi rasa nyaman, kasih sayang dan pada akhirnya manusia dapat mencapai tujuan hidup yaitu damai, bahagia dan sejahtra. Jadi kesejahtraan itu dapat diujudkan dengan mengatur hubungan seimbang harmonis antar aspek; parhyangan, pawongan dan palemahan dalam konsep Agama Hindu disebut Tri Hita Karana (Wiana,1995). Umat Hindu memiliki keyakinan yang kuat akan keberadaan aspek Tri Hita Karana sapat menuntun umat menujuju hidup bahagia dan sejahtera. Oleh karena itu konsep ajaran ini harus dipahami dan diterapkan dalam kehidupan sehari-hari. Hasibuan (2000) menyatakan bahwa tri pusat pendidikan meliputi: keluarga, sokolah dan masyarakat memberi kontribusi yang efektif dalam menumbuh-kembangkan kepribadian yang kuat bagi generasi muda. Berbicara malasah alam tidak bisa lepas dari lingkungan secara umum yang mencakup lingkungan hidup dan lingkungan mati. Lingkungan hidup meliputi unsur tanaman, binatang, manusia. Manusia disamping termasuk dalam aspek lingkungan dalam konsep Tri Hita Karana adalah juga menjadi aspek pawongan. Menata alam palemahan tidak bisa lepas dari membina sikap dan perilaku manusia. Implementasi tri hita karana berkaitan dengan pembangunan dibidang lingkungan yang menghadapi berbagai masalah. Segala bentuk masalah berkenaan dengan lingkungan yang dihadapi sampai saat ini adalah masalah yang dipandang dari sudut kepentingan manusia. Masalah itu timbul karena adanya perubahan lingkungan, sehingga lingkungan itu tidak sesuai lagi untuk 
mendukung kehidupan manusia dan kesejahteraannya. Dalam masalah lingkungan yang dipersoalkan ialah perubahan yang diakibatkan perbuatan umat manusia. Perkembangan jumlah penduduk yang disertai kebutuhan yang semakin meningkat dapat memicu intervensi terhadap alam, menjadi semakin besar pula, (Soemanwoto, 1989). Intervensi manusia yang berlebihan terhadap lingkungan mengakibatkan kerusakan pada alam seperti: pencemaran air bersih, polusi udara, banjir, kekeringan dan tanah longsor di musim hujan (Wiana, 1992). Dalam pandangan Agama Hindu konsep pengelolaan lingkungan harus tetap memperhitungkan keharmisan dan keseimbangan yang disebut dengan Tri Hita Karana (Gama, 2002). Sebagaimana pendapat bahwa manusia yang dianggap sebagai mahluk yang paling mulia di bumi ini karena memiliki bayu, sabda, dan idep. Salim, (1986) menyatakan bahwa pembangunan hendaknya terarah pada membangun manusi dan masyarakat Indonesia seutuhnya mencakup: pembangunan lahiriah yaitu pangan, sandang, perumahan dan lain-lain, pembangunan batiniah; pendidikan, rasa aman, keadilan, dan kesehatan. Disamping itu keberadaan sumber daya air, tanah dan lahan menjadi semakin terbatas, yang berarti menurunnya daya dukung lingkungan sebagai akibat dari pada semakin bertambahnya penduduk, penggeseran pola hidup dan dampak dari kegiatan pembangunan. Adanya fenomena yang menunjukkan bahwa upaya manusia memanfaatkan sumber daya dengan mengeksploitir dan memanfaatkan sumber daya alam dengan cara yang tidak bijaksana menyebabkan kondisi sumber daya alam menjadi rawan dan menjadi ancaman bagi kehidupan umat manusia, misalnya kekeringan, banjir, tanah longsor, erosi, polusi, dan sebagainya. (Somarwoto 1989). Oleh karena itu keberadaan sumber daya manusia menjadi penentu terhadap kondisi lingkungan hidupnya, baik secara individu maupun secara kolektif melalui suatu sistem kelembagaan seperti sekolah. Untuk itulah perlu adanya tuntunan untuk keseimbangan hidup yang disebutkan pada Tri Hita Karana. Dari keseimbangan hidup ini begitu terkenal di Indonesia khususnya bagi umat Hindu di Bali. Mengenal konsep tentang keseimbangan hidup meerupakan penuntun manuasia agar memperoleh kehidupan yang aman, damai dan sejahtra. Nala (1995) Tri Hita Karana belum dilaksanakan sesuai dengan konsep teori, masih banyak pelanggaran yang dilakukan oleh manusia yang paling banyak dilanggar adalah unsur palemahan (alam). Demikian halnya yang ditemukan pada SMP Negeri 5 Singaraja yang beralamat di Desa Penglatan, Kecamatan dan Kabupaten Buleleng. Di sekolah tersebut pembangunan pawongan menjadi prioritas utama dalam kaitannya pengendalian lingkungan alam (palemahan) yang bersih, seimbang dan harmonis. Perlu diketahui bahwa sekolah tersebut sangat berhasil dalam memanfaatkan pawongan untuk menata lingkungan dengan konsep Tri Hit Karana. Berdasarkan hal tersebut menjadi sesuatu yang menarik untuk diketahui magaimana manajemen sekolah dalam pengelolaan pengelolaan lingkungan berdasarkan konsep atri ahita Karana. Tri Hita Karana yang menjadi azas seluruh masyarakat memberi isyarat bahwa dalam pengelolaan lingkungan fisik alam agar dilakukan secara bijaksana untuk mecapai suatu harmoni atau lestari sehingga sumber daya alam memberi manfaat yang sebesr-besarnya untuk kehidupan manusia dalam rentang waktu yang tidak terbatas. Ini berarti, harus ada upaya konservasi sumber daya alam dan terhindar dari kerusakan yang membahayakan bagi kehidupan. Disinilah peran Tri Hita Karana sebagai landasan hidup manusia di dalam melaksanakan aktivitas, agar apa yang telah dilaksanakan dapat berdampak positif bagi kehidupan manusia yang akan datang. Untuk mengkaji mengkaji permasalahan di atas digunakan kajian konsep dan teori antara lain: konsep yang berkaitan dengan pengertian tri hita karana, 
aspek-aspek tri hita karana, keseimbangan dan keharmonisan lingkungan. Landasan teori yang digunakan antara lain: behaviorisme dari . Thorndike (dalam Purwanto, 2002) yang menekankan pada perilaku individu dapat tumbuh dan berkembang stimulud atau respon. Perilaku individu dapat diarahkan atau dituntun sesuai dengan tujuan yang diinginkan. Grand teori yang lain yaitu humanitik dari Abraham H. Maslow, dan Carl Rogers (dalam Madrasuta, 2005) menjelaskan bahwa karakteristik teori ini adala: mengutamakan pembelajar sebagai pribadi yang unggul, memfokuskan pembelajaran dalam tekad dan motivasi pribadi, memfokuskan pada fungsi afektif dan kognitif, mementingkan adanya pengenalan diri dan self concept, memprioritaskan perspektif diri pada setiap diri individu, mendahulukan peningkatan dalam self control, memprioritaskan ilmu pengetahuan dasar dan pengalaman. Teori lain yang digunakan untuk membedah fakta temuan penelitian digunakan beberapa teori sosial yaitu: teori setrukturalisme, teori fungsi dan makna dari Riswandi dan Titin Kusmini, (dalam Gama, 2002) dan teori hegemoni dari Antonio Gramce, 1913 (dalam Gama, 2002).

\section{METODE}

Rancangan yang digunakan dalam penelitian ini adalah rancangan deskriptif kualitatif. Subjek penelitian ini adalah guru dan siswa di SMP Negeri 5 Singaraja. Sementara Objek Penelitian ini adalah Implementasi Tri Hita Karana yang melandasi SMP Negeri 5 Singara sesuai hak dan kewajiban masyarakat sekolah baik sebagai siswa, guru maupun penyelenggara administrasi pendidikan. Metode Pengumpulan adalah metode wawancara, observasi, dan analisis dokumen. Data yang terkumpul dianalisis dengan menggunakan model analisis interaktif yang meliputi langkah-langkah (1) reduksi data (2) penyajian data (3) penyimpulan data atau verifikasi data.

\section{HASIL DAN PEMBAHASAN}

Setrategi penerapan Tri Hita Karana dapat dilihat dari aspek parhyangan, pawongan dan palemahan.

\section{Parhyangan.}

Penerapan konsep Parhyangan dalam pembelajaran. Konsep parhyangan diterapkan melalui insersi atau penyisipan dalam pelajaran untuk setiap guru. Tidak hanya guru Agama tapi semua guru bisa menyisipkan konsep keyakinan beragama kepada siswa. Hal tersebut dilaksanakan dari orientasi siswa baru sampai menjelang tamat tetap terus dilaksanakan oleh guru kepada siswanya. Penerapan ini tidak hanya dalam proses pembelajaran di dalam kelas juga di luar kelas. Penerapan di luar kelas seperti pelajaran olah raga, pramuka, ekstra kurikuler dan sejenisnya termasuk waktu istirahat. Guru menanamkan model pengawasan melekat pada anak dalam rangka menjaga makna keseimbangan hubungan keharmonisan manusia dengan Tuhannya. Penerapan yang dilakukan integral dalam proses pendidikan dan pembelajaran dapat menumbuhkan pembiasaan dan pembudayaan perilaku yang harmonis seimbang dengan Tuhan. Gejala natural yang nampak pada siswa adalah jujur, ramah, rajin sembahyang. Ini terlihat dari perilaku siswa yang cinta akan tanaman bertuah atau tanaman bunga yang digunakan untuk pelaksanaan upacara. Dalam memfasilitasi sikap dan perilaku ritual atau religius siswa, maka sekolah menyiapkan beberapa tempat suci yaitu: Padmasana sekolah, taksu, 
sanggah lebuh di pintu masuk sekolah, penunggun atau sedahan karang serta menempatkan pelangkiran sebagai pengayatan pada ruang-ruang kelas, ruangan kantor guru dan pegawai. Sebelum dan sesudah jam pelajaran siswa melakukan persembahyangan Puja Tri Sandhya. Penerapan konsep parhyangan melalui pelaksanaan upacara keagamaan. Pelaksanaan atau implementasi konsep parhyangan hanya dilaksanakan pada setiap hari raya keagamaan yaitu: hari raya Saraswati, purnama dan tilem, sedangkan hari raya yang lain tidak diharuskan. Pada hari-hari raya tersebut siswa yang dikoordinir melalui kegiatan OSIS yang dibimbing oleh guru pembina OSIS dan guru-guru lainnya melakukan berbagai kegiatan mulai dari gotong royong atau kerja bhakti membersihkan semua parhyangan, menghias atau memasang busana pelinggih, menyiapkan sarana upakara dan sejenisnya. Kegiatan lain yang terkait adalah berbagai lomba yang mencerminkan menjaga kelestarian budaya, keharmonisan hubungan atau bhakti kepada Tuhan Yang Maha Esa antara lain: Iomba majejaitan, lomba membuat kelatkat bagi siswa peria, lomba membuat pajegan dan pesantian. Tujuan yang diinginkan adalah peningkatan serada bhakti dan meningkatkan rasa cinta kasih terhadap semua ciptaan Tuhan. Sekolah juga mengimplementasikan konsep parhyangan melalui kegiatan tirtayatra atau dharmayatra ke luar sekolah. Penerapan konsep parhyangan terkait pengelolaan lingkungan. Bentuk pengelolaan lingkungan tercermin dari penataan bangunan-bangunan suci pada SMP Negeri 5 Singaraja sudah terlihat dari struktur dan komposisi bangunan-bangunan sucin yang memberi ruang untuk menanam tanaman dan bunga bertuah pada areal bangunan suci. Siswa diberi pemahaman yang berhubungan dengan keberadaan bangunan pelinggih yang ada di sekolah. Makna kesucian/kebersihan, kesakralan yang harus ditindaklanjuti dengan sikap dan perilaku religius, seperti: tidak boleh berbicara kasar di areal pelinggih, berpakaian atau busana adat, tidak boleh membuang sampah sembarangan di areal pura. Penanaman sikap dan perilaku tersebut dilakukan secara kontinyu dan berkesinambunga. Setrategi yang diterapkan oleh sekolah adalah setrategi pembudayaan karakter. Sebagai bentuk pembudayaan karakter religius adalah sekolah memiliki suasana akademik yang religius: tenang, nyaman, menyenangkan, dengan suasana sejuk rindang karena banyak pohon perindang seperti berbagai jenis pohon kelapa, pohon rijasa dan beraneka ragam bunga untuk keperluan upacara. Penerapan konsep Parhyangan dalam tatanan Dewa Yadnya. Keseimbangan dan keharmonisan yang diharapkan sebagai wujud hubungan manusia dengan Ida Sang Hyang Widhi Wasa dalam bentuk pelaksanaan upacara-upacara/piodalan diseluruh bangunan suci yang ada. Upacara agama yang ada hubungannya dengan lingkungan yang dilaksanakan disekolah adalah berupa Dewa Yadnya dan Bhuta Yadnya. Pelaksanaan upacara dewa yadnya yang berhubungan dengan lingkungan alam yang di laksanakan oleh SMP Negeri 5 Singaraja merupakan suatu persembahan atau tanda bakti kepada lda Sang Hyang Widhi Wasa. Upacara Dewa Yadnya yang dilaksanakan yang ada kaitannya dengan lingkungan adalah: Tumpek Wariga atau Tumpek Uduh dan Pengatag. Upacara ini dirayakan seriap hari Sabtu Keliwon wuku Wariga (urutan wuku ketujuh). Juga diselenggarakan untuk memohon keeselamatan melalui suatu upacara kehadapan Ida Sang Hyang Widhi Wasa. Upacara ini ditunjukkan pada Dewa Sangkara yaitu menifestasi Sang Hyang Widhi sebagai dewa tumbuh-tumbuhan. Tanaman dibuatkan upacara dengan maksud agar tanaman dapat membantu manusia dengan memberikan hasil yang berlimpah untuk kesejahteraan umat manusia. Upacara ini dilaksanakan SMP Negeri 5 Singaraja berdasarkan yang 
termuat dalam pustaka suci Rontal Sundarigama (dalam Titib, 1996) sebagai berikut.

Wariga Saniscara Keliwon ngaran,

Puja kertinira Sang Hyang Sangkara,

Apan sira umerdiaken sarwaning tumuwuh,

Kayu-kayu kunang, widi widanania peras, tulung,

Sesayut, tepung bubur mwang tumpeng agung,

Iwaknia guling dadi, patikwenang, sha raka,

Penyeneng tetebus, kalingania anguduh ikang tanem tuwuh,

Asetana sekar awoh agodong, dadiya urip ikang sarwa janma,

Maksudnya :

Pada hari sabtu keliwon wuku wariga disebut Tumpek Pengunduh, pemujaan terhadap Sanghyang Sangkara, beliaulah yang menghidupkan segala jenis tumbuh-tumbuhan seperti sebagai jenis kayu-kayuan. Upacara upakaranya terdiri dari; peras tulung, sesayut, bubur tepung dan tumpeng agung memakai daging guling dilengkapi dengan jajan dan buah-buahan. Penyeneng tetbus dipakai sarana untuk menyuruh semua jenis tumbuh-tumbuhan agar dapat berdaun, berbunga, dan berbuah yang lebat untuk membantu kehidupan manusia.

Bhuta Yadnya, upacara ini merupakan bentuk pengamalan konsep parhyangan melalui pecaruan yang bertujuan untuk memohoh agar Hyang Widhi Wasa memberkati keharmonisan atau kelestarian alam yang dapat memberi kehidupan dan kesejahtraan manusia. Artinya, alam telah beryajna kepada manusia dan karenanya manusiapun wajib beryajna kepada alam. Dalam hubungannya dengan Tri Hita Karana. Begitu halnya dengan Warga SMP Negeri 5 Singaraja percaya bahwa untuk menyelaraskan alam ini persembahan diwujudkan dengan Bhuta Yajna yang memliki wujud ritual. Persembahan diluar dari manusia secara individu yaitu lingkungan alam dan lingkungan manusia. Ini harus diwujudkan dalam bentuk Bhutahita dan Jagadhita. Bhutahita yang mensejahterakan Panca Maha Bhuta, tumbuh-tumbuhan dan binatang atau sarwaprani. Sedangkan untuk mewujudkan Jagadhita atau kehidupan bersama yang harmonis diwujudkan dengan jagatkerti : jaghat yang benar-benar tertib dan sejahtera. Hal ini merupakan upaya dalam menyiapkan Bhuana Agung sebagai individu, setiap orang harus menyiapkan dirinya lahir batin. Ada dua jenis tawur atau bhuta yadnya yang dilaksanakan disekolah yaitu: tawur kesanga dan bhuta yadnya/pecaruan.

\section{Tawur Kesanga.}

Tujuan tawur atau pecaruan adalah sebagai sarana untuk nyomya atau menetralisir semua kekuatan-kekuatan yang bersifat negatif yang ada didalam Bhuna Agung atau alam semesta, dan Bhuana Alit atau pada diri setiap warga sekolah. Keselarasan dan keserasian antara Bhuana Agung dan Bhuana Alit dapat dipertahankan secara berkesinambungan, untuk mencapai tujuan akhir dari ajaran agama yaitu Moksartham Atmanan.Upacara Bhuta Yajna. Pelaksanaan pecaruan yang insidental atau sewaktu-waktu merupakan yadnya kepada manifestasi Tuhan yang mengatur alam bawah (Bhur Loka) agar terjaga keharmonisan dan keseimbangannya. Di alam yang seimbang dan harmonis diyakini dapat memberi kekuatan bagi manusia untuk melakukan aktivitas sesuai dengan profesinya. Tugas siswa dan guru adalah melaksankana pembelajaran. Guru mengajar dan mendidik dan siswa belajar. Semua proses tersebut akan optimal jika alam atau tempat belajar mengajar dalam suasana harmonisseimbang sekala dan niskala. Dalam filosofi Hindu keseimbangan yang 
dimaksudkan adalah buana agung (alam semesta) dan buana alit (diri sendiri). Jadi pecaruan juga bermakna membuat keseimbangan diri para siswa dan guru di sekolah.

\section{Pawongan}

Konsep pawongan dalam ajaran Tri Hita Karana adalah keseimbangan atau keharmonisan hubungan antara pawongan dengan Tuhannya dan juga antara pawongan dengan pawongan. Setrategi dalam membina hubungan ini dilakukan dengan menyasar aspek kognetif, afektif dan psikomotorik. Melalui insersi pembelajaran semua guru wajib dapat menyisipkan nilai-nilai Tri Hita Karana (THK) melalui mata pelajaran yang diajarkannya baik di dalam kelas maupun di luar kelas. Kegiatan di luar kelas dapat dilakukan melalui pendekatan kurikuler, ko-kurikulel dan tatakrama pergaulan sosial di sekolah. Pendekatan kurikuler yang dimaksudkan dimana guru dalam pepbelajaran menggunakan metode atau model pembelajaran karya wisata; siswa diajak mengamati objek secara langsung ke luar kelas. Sambil belajar siswa diajarkan agar tetap menghargai tempat yang disucikan seperti parhyangan atau pelinggih, menghargai asta kosala-kosali dan lain-lain. Pendekatan kegiatan kokurikuler seperti; Pramuka, Seni tari dan tabuh, pesantian dan lain-lain. Pendekatan tatakrama pergaulan sosial di sekolah siswa dibina untuk tetap menerapkan sikap dan perilaku saling menghargai, saling menghormati, saling membantu dan memberi yang dikenal dengan konsep sagilik saguluk salunglung sabyantaka sarpa na ya. Setrateginya penerapan nilai THKnya adalah: a) pengenalan nilai, b) pemahaman, c) pembiasaan, d) pembudayaan. Arah dan sasarannya adalah diperoleh sikap dan perilaku siswa yang mencerminkan budaya pengamal THK dalam kehidupan sekolah, di dalam keluarga dan di masyarakat. Khusus pada siswa nilai-nilai THK sudah membudaya pada masing-masing siswa. Hal ini ditemukan dalam observasi terhadap sikap dan perilaku siswa di sekolah. Melihat jumlah peserta didik SMP Negeri 5 Singaraja pada Tahun Pelajaran 2018/2019 terdiri dari klas VII 348 orang, VIII 337 orang dan IX sebanyak 350 orang jadi jumlah keseluruhan siswa SMP Negeri 5 Singaraja adalah 1035 siswa. Dari seluruh siswa 1015 orang siswa beragama Hindu, 17 orang siswa beragama Budha, 2 orang siswa beragama Islam, dan 1 orang beragama Kristen. Implementasi Tri Hita Karana tercermin pada kegiatan yang dilakukan siswa, hampir seluruh siswa yang datang ke sekolah secara perorangan berdoa/sembahyang di Parhyangan sekolah sebelum mereka melakukan kegiatan lain. Sebagian besar siswa jika menemukan sampah yang urai sembarangan diambil kemudian dibuang ke bak sampah baik di luar kelas maupun di dalam kelas. Hampir seluruh siswa tidak pernah membuang sampah sembarangan (tidak pada tempatnya). Hanya sebagian kecil siswa yang melanggar tatatertib sekolah, hal ini mencerminkan mereka telah mengamalkan atau menjaga keharmonisan hubungan antar teman dan gurunya. Kebersihan kelas dan lingkunganya diatur dengan membentuk piket kebersihan yang bertugas membersihkan sebelum pelajaran mulai menjaga selama pembelajaran berlangsung dan menata ulang bangku-bangku diakhir pelajaran agar tetap rapi. Pawongan dari unsur guru dan staf pegawai juga mempunyai peran atau tugas masing-masing. Sebagai warga sekolah yang bertugas menggerakkan semua aktivitas melalui mekanisme kerja untuk mencapai tujuan (Suastika, 2005). Sesuai dengan job atau tugas masing-masing setrategi kepemimpinan yang diterapkan adalah melalui pendidikan dan pengajaran. Mendidik menekankan pada pembinaan sikap dan perilaku sedangkan mengajar menumbuh kembangkan kecerdasan siswa (Ritzer, 2003). Kepala sekolah merupakan 
pimpinan selaku pengontrol serta pengambil kebijakan yang berkaitan dengan semua kegiatan sekolah. Peraturan-peraturan sekolah, kode etik guru dan tatatertib siswa diterapkan sebagai dasar untuk menjalin keharmonisan hubungan pawongan. Pembinaan atas pelanggaran peraturan terus diupayakan secara kontinyu dan berjenjang kepada warga sekolah dengan memberi peringatan sampai sanksi tertentu disesuaikan dengan tingkat pelanggarannya. Dengan demikian diharapkan tumbuh pembudayaan sikap dan perilaku yang mencerminkan nilai Tri Hita Karana (keseimbangan/keharmonisan). Terbinanya sikap dan perilaku pawongan pada SMPN 5 Singaraja tercermin pada penataan sekolah dengan lingkungan bersih, asri dan sehat warga sekolahnya. Konsep sagilig saguluk salunglung sarpa na ya berjalan dengan baik yang sering disebut dengan manyama braya. Hal ini nampak dalam kegiatan kebersihan gedung sekolah maupun ruangan kelas dilakukan secara bersama-sama oleh siswa yang dilakukan setiap pagi 15 menit sebelum melakukan kegiatan belajar mengajar dan 5 menit sebelum jam pulang sekolah memberdayakan tukang kebun dan kebersihan untuk menjaga agar lingkungan sekolah selalu dalam keadaan bersih.

\section{Palemahan}

SMP Negeri 5 Singaraja memiliki batas-batas wilayah yaitu: sebelah timur berbatasan dengan wilayah Desa Jineng Dalem, sebelah selatan berbatasan dengan lingkungan Desa Alas angker, sebelah barat berbatasan dengan daerah lingkungan Banyuning Selatan dan Sebelah Utara berbatasan dengan daerah lingkungan Penarukan. Posisi sekolah dikelilingi desa yang padat penduduknya merupakan tantangan dan ancaman terhadap kebersihan lingkungan. Namun hal itu tidak terjadi karena warga sekolah dengan warga desa setempat menjalin kerja sama dalam menangani kebersihan dan keamanan lingkungan sehingga tertimbunnya sampah pendatang atau impor tidak terjadi pada masing-masing wilayah termasuk di SMPN 5 Singaraja. Sejalan dengan Undang-undang Nomor 23 Tahun 1997 dinyatakan bahwa sekolah berupaya memberdayakan semua komponen atau potensi seperti ruang, benda, daya, keadaan dan mahluk hidup termanusia harus berada dalam posisi yang tepat dan benar untuk mencapai kesejahteraan manusia dan mahluk lainnya (UU, No 23 tahun 1997). Staf sekolah secara bersama sama dengan warga desa melestarikan fungsi lingkungan hidup masing-masing melalui penataan, pemanfaatan, pengembangan, pemulihan, pengawasan, dan pengendalian lingkungan secara berkesinambungan. Pengelolaan lingkungan sekolah diselenggarakan dengan asas tanggung jawab, berkelanjutan, dan asas manfaat bertujuan untuk menjadikan sekolah berwawasan hijau bersi dan bertatakrama sesuai dengan konsep Tri Hita Karana. Reg Veda IV.26.2 (dalam Lali Yogantara, 2006) berbunyi:

\section{Aham bhunimadadamaryayaha \\ Vrstim disuse martayaya \\ Ahamapo anayam vavssaba mama \\ Devaso anu ketamayan}

Artinya: 
Aku memberikan bumi kepada orang-orang baik dan hujan serta udara untuk manusia, wahai para bijaksana, datanglah kepadaku dengan keinginan yang penuh.

Dalam Mantra Veda di atas disebutkan bahwa Hyang Widhi memberikan Ibu pertiwi kepada orang-orang yang baik, dan selanjutnya mereka berkewajiban menyebarluaskan kebaikan dan memberantas kejahatan, ibu pertiwi adalah ibu yang selalu memberikan makanan, minuman hak atas tempat tinggal bersama, oleh karenanya manusia harus mampu memelihara keutuhan dan kelestariannya. Menyadari hal tersebut SMP Negeri 5 Singaraja melakukan penataan lingkungan sekolah dan terus berupaya untuk melakukan perbaikanperbaikan sehingga kedepan keasrian dan kenyamanan sekolah tetap terjaga. SMP Negeri 5 Singaraja merupakan salah satu sekolah di Kabupaten Buleleng yang memiliki jumlah siswa sangat banyak yang terdiri dari siswa beragama Hindu 1015 orang siswa, beragama Buda 17 orang siswa,beragama Kristen 1 orang siswa,beragama Islam 2 , ini dapat dilihat dari jumlah siswa yang beragama hindu dan beragama lain yang hampir tidak pernah terjadi perselisihan, walaupun siswa dari SMP Negeri 5 Singaraja menganut keyakinan yang berbeda, hal ini tidak memghalangi pihak sekolah melakukan sesuai konsep Tri Hita Karana, ini dapat ditemukan dari bangunan padmasana serta tanaman-tanaman yang menunjang kegiatan seperti bunga-bungaan dan tanaman untuk peneduh, Tata Letak bangunan juga tertata sehingga tidak menyalahi Asta Kosala-kosali seperti padmasana terletak pada utamaning mandala,Gedung-gedung penunjang kegiatan sekolah terletak pada madya mandala, serta tempat sampah atau kamar mandi terletak pada nisata mandala, sampah-sampah organik dan nonoganik dipilah untuk di daur ulang. Berbicara tentang kondisi lingkungan SMP Negeri 5 Singaraja, dapat lihat dari kondisi fisik bangunan gedung yang ada , taman sekolah, serta selokan yang ada pada depan tiap ruang kelas. Kondisi Pisik Bangunan gedung SMP Negeri 5 Singaraja dalam kondisi sangat baik, ini dikarenakan setiap tahunnya selalu dilakukan rehab ataupun perbaikan tehadap gedung. Taman SMP Negeri 5 Singaraja ditata sedemikina rupan dari tanaman yang memiliki khasiat untuk obat (Toga), tanaman yang berfungsi sebagai upacara dan tanaman yang berpungsi sebagai peneduh ditata sedemikian rupa, sedangkan untuk selokan yang ada pada setiap rungan kelas dibuat dengan baik sehingga kalau ada air hujan bisa mengalir dengan baik. Semua personal sekolah mempunyai komitmen yang kuat untuk menangani sampah pelastik. sebab sampah plastik ini merupakan sampah-sampah berasal dari sampahsampah sisa kemasan makanan dan minuman ringan yang dibeli oleh siswa. Mengenai sampah plastik, pihak sekolah terlebuh dahulu mensosialisasikan tentang pemahaman sampah pelastik kepada semua personal sekolah. Menyadari hal tersebut pihak sekolah melalui OSIS (organisasi siswa intra sekolah) berupaya mengumpulkan sampah plastic. Melalui OSIS pihak sekolah berupaya agar sampah pelastik yang tidak bisa terurai tersebut dimanfaatkan supaya bisa didaur ulang dijadikan barang-barang yang mempunyai manfaat seperti tas, hiasan dinding, maupun lain yang berguna, nantinya benda hasil daur ulang ada yang dijual dan ada yang digunkan hiasan ruang kelas. Walaupun dengan harga yang relatife sangat murah namun kegiatan ini sangat membantu dalam pengulangan masalah sampah pelastik. Dalam perjalanan pembinaan tentang internalisasi nilai Tri Hita Karana ditemukan beberapa faktor penghambat yaitu: dari hasil analisis lingkungan terhadap tempat SMPN 5 Singaraja yaitu berada di daerah pedesaan yang di kelilingi oleh desa yang padat penduduknya. Penduduk yang padat berpotensi menghasilkan limbah berupa sampah keluarga 
yang cukup banyak dan sebagian dari limbah tersebut terbuang di areal sekolah dan lingkungan sekitar sekolah. Belum lagi banyaknya binatang liar seperti anjing dan ayam yang menyebarkan limbah tersebut. Disamping jumlah penduduk menjadi faktor penghambat, juga bisa menjadi tantangan bahwa mayoritas penduduk disekitar sekolah adalah beragama Hindu. Secara umum masyarakat telah paham terhadap pengamalan Tri Hita Karana dalam kehidupan sehari-hari. Mereka memahami cara memelihara lingkungan yang bersih dan sehat. Jadi faktor motivasi merupakan faktor dalam diri masing-masing warga masyarakat. Sampai saat ini faktor motivasi rendah akan kebersihan lingkungan masih ada pada masyarakat. Oleh karena setrategi pembinaan dalam pengamalan Tri Hita Karana di sekolah ini cukup bagus maka faktor motivasi rendah terhadap kebersihan lingkungan dapat diperkecil. Sejalan dengan teori dalam Kamus besar Bahasa Indonesia (2001) disebutkan bahwa motivasi mendorong sikap dan perilaku seseorang untuk merespon dan bertidak guna mencapai tujuan yang diinginkan baik secara individu ataupun kelompok atau masyarakat. Pembinaan dapat memberi pengetahuan dan wawasan kepada seseorang sehingga yang bersangkutan dapat mengambil keputusan sesuai dengan tujuan yang diinginkan. Tri Hita Karana sudah jelas memberikan petunjuk dan arah yang tepat melalui keyakinan kognetif yang menggerakkan afektif dan psikomotorik. Kerjasama yang baik dengan masyarakat sekitar, dalam beberapa hal seperti pendidikan, sosial, seni dan budaya merupakan modal untuk mempercepat proses pencapaian tujuan pendidikan yang cakap/cerdas berkarakter Pancasila. Hal ini tidak terlepas dari tujuan Agama Hindu yaitu menjadikan umat/manusia moksartham jagadhita ya ca iti dharma.

\section{Dampak Implementasi Tri Kita Karana Terhadap Manusia}

\section{Parhyangan}

Konsep Tri Hita Karana merupakan konsep yang sangat baik dan mempunyai makna yang tinggi. Akan tetapi sering kali konsep ini tiddak berjalan dengan baik disebabkan hubungan manusia dengan lingkungannya yang kurang harmonis. Alam akan memberikan hukuman kepada mereka yang menghilangkan sumberdaya alam. Manusia hanya memikirkan, merencanakan, dan melaksanakan berbagai ide dan gagasan dalam rangka peningkatan mutu kehidupan, sedangkan keberhasilannya sangat tergantung kehendak dari Ida Sanghyang Wdhi Wasa. Keyakinan umat hindu ini menempatkan Hyang Widhi sebagai maha penentu keberhasilan manusia didalam mewujudkan tujuan yang telah di tetapkan terlebih dahulu. Dalm hubungan dengan ini pustaka suci veda menegaskan: Pudja (2004) dalam bukunya Atharwaweda (IX.19.21) tak seorangpun akan mencapai kebahagiaan tanpa meyakini akan kebesaran Hyang Widhi. Pudja (2004) Atharwaveda (XXVI.3) Hyang Wdhi, Engkau adalah sumber kehidupan, sumber kecerdasan, dan sumber kebahagiaan, pencipta alam semesta, hamba menuju-MU yang bercahaya, hamba mohon bersedialah Engkau memberi tuntunan yang benar kepada kecerdasan budi pekerti hamba. Pudja (2004) Atharwaweda ( XX.18.3) Hyang Widhi hanya menyayangi orang yang bekerja keras, ia membenci orang yang malas, mereka senantiasa sadar terhadap dharma akan mencapai kebahagiaan tertingggi. Dari kutipan di atas, memberi informasi tentang hindu bahwa seorang atau sekelompok orang dalam hal ini warga sekolah di dalam upaya mencapai tujuan yang berhubungan dengan dharma Negara maupun dharma Agama manusia harus yakin terhadap Tuhan, berdoa dan bekerja keras. 


\section{Pawongan}

Dalam makrokosmos (Bhuana Agung) disebutkan bahwa unsur Tri Hita Karana itu meliputi jiwa alam (Brahman) manusia memiliki sabda, bayu dan idep (suara, tenaga dan pikiran) sebagai penggerak atau pengelola alam, dan fisik alam selaku tubuh dasar alam (Bapeda Bali dan Bali Trevel News, 2004). Sesuai dengan konsep tersebut yang paling menentukan eksistensi alam adalah Brahman, karena Brahman adalah sang pemberi jiwa yang memberikan hidup dan kehidupan kepada manusia, karena manusia sebagai pengelola dan penggerak alam. Dalam kehidupan nyata bahkan manusia adalah penentu utama terhadap alam. Hal ini sesuai dengan pendapat Sumaatmadja(1998:93-96) bahwa manusia adalah merupakan faktor dominan terhadap lingkungan, karena manusia dapat menguasai ilmu pengetahun dan teknologi dan pemanfaatannhya dalam berbagai bidang kehidupan dalam upaya meningkatkan kesejahtraan. Dalam pengelolaan lingkungan, manusia dipandang sebagai sumber daya yang memiliki peran dan fungsi, yaitu sebagai penggerak sumber daya yang lainnya untuk tercapainya suatu tujuan. Manusia sebagai sumber daya menurut Gorda (1994:9) memiliki kemampuan potensional yang terdiri dari kemampuan berpikir, kemampuan berorganisasi, kemampuan moral, kemampuan melaksanakan sesuatu yang bersifat teknis dan kemapuan pengalaman, kemampuan tersebut merupakan penentu yang dapat mempengaruhi perilaku manusia di dalam mencapai tujuan hidupnya baik individu maupun bersama. Implementasi konsep Tri Hita Karana yang tepat dan benar pada SMPN 5 Singaraja berdapak pada hasil yang diperoleh sekolah dalam berbagai kegiatan yang diikuti oleh sekolah yaitu: menerima penghargaan Wawasan Adi Wiyata Tingkat Nasional Tahun 2018 dan juara ke dua Lomba Usaha Kesehhatan Sekolah (UKS) tingkat Provinsi Tahun 2018 serta Lomba Sekolah Sehat Tingkat Provinsi dengan meraih juara ke dua, keberhasilan yang dicapai SMP Negeri 5 Singaraja telah membuktikan bahwa warga sekolah telah mampu mengolah dan menjaga lingkungan sekolah.

\section{Palemahan}

Tri Hita Karana pada hakikatnya adalah sikap yang seimbang antara memuja Hyang Widhi dengan mengabdi pada sesama manusia serta mengembangkan kasih sayang kepada alam lingkungan, maka dampak yang dapat diwujudkan diantaranya adalah: 1) lingkungan sekolah menjadi bersih,sejuk dan indah, 2) suasana belajar siswa yang menjadi nyaman dan menyenangkan, 3) penataan taman sekolah yang menjadi asri, 4) kesehatan warga sekolah lebih aman dan meningkat. Kondisi tersebut adalah kondisi yang dibutuhkan oleh setiap manusia, oleh karena itu konsep palemahan ini dapat menumbuh kembangkan sikap dan perilaku untuk menjaga kelestarian, keseimbangan lingkungan alam agar tetap bersih dan sehat.

\section{PENUTUP}

\section{Simpulan}

Implementasi Tri Hita Karana pada SMP Negeri 5 Singaraja telah berjalan dengan baik yang dilakukan oleh setiap warga sekolah mulai dari siswa, pegawai, guru dan staf pimpinan. Setrategi yang digunakan dalam pembinaan 
adalah pendekatan setruktural dengan sasaran pemahaman dan penerapan pengetahuan tentang Tri Hita Karana dalam kehidupan sehari-hari di sekolah dan luar sekolah. Khusus pemahaman pengetahuan Tri Hita Karana untuk siswa dilakukan melalui insersi mata pelajaran untuk semua materi pelajaran atau semua guru wajib melaksanakan insersi nilai-nilai Tri Hita Karana melalui mata pelajaran yang diajarkannya. Jadi bukan hanya untuk mata pelajaran Agama Hindu dan Budi Pekerti saja. Disamping jalur kurikuler juga melalui ekstra kurikuler seperti: kegiatan pramuka, olahraga, seni tari, tabuh, pesantian dan seni nasional. Kegiatan persembahyangan purnama tilem, hari raya Saraswati dan upacara tertentu yang dilaksanakan sekolah merupakan bagian dari setrategi pengamalan nilai-nilai Tri Hita Karana. Faktor yang menghambat pelaksanaan Tri Hita Karana pada SMPN 5 Singaraja antara lain: faktor letak sekolah yang dikelilingi oleh desa yang padat penduduknya, letak sekolah yang luas dan tidak datar, jumlah kelas atau bangunan gedung yang banyak, jumlah tanaman perindang yang banyak. Semua faktor di atas membutuhkan perencanaan yang matang. Dampak terhadap personal atau warga sekolah tumbuh dan terbinanya keyakinan terhadap Tuhan, sikap dan perilaku untuk saling menyayangi antar sesama manusia, menyayangi semua ciptaan Tuhan dengan mewujudkan kebersihan, kenyamanan, kedamaian dan kesejahtraan.

\section{DAFTAR PUSTAKA}

Bapeda Bali dan Bali Travel News. 2002. Buku Panduan Tri Hita Karana di Sekolah dan Kantor Pemerintah. Denpasar.

Gorda, I Gusti Ngurah, 1994. Manajemen Sumber Daya Manusia. Denpasar: PT Widya Karya Gematama

Gama, I Wayan 2002. Reformasi Agama Hindu Menuju Kebertahanan Sradha Dalam Menjawab Tantangan Masa Kini. Tesis tidak diterbitkan. Denpasar: Program Pasca Sarjana Universitas Udayana Program Studi Magister (S2).

Hasibuan, MS., 2000. Manajemen Sumber Daya Manusia dan Kunci Keberhasilan. Jakarta: CV. Haji Mas Agung.

Kamus Besar Bahasa Indonesia. 2005. Edisi Ketiga, Jakarta: Balai Pustaka.

Lali Yogantara, 2006. Makalah Lingkungan Hidup Dalam Perspektif Hindu. Denpasar: Tidak diterbitkan.

Madrasuta, I Ngakan Made. 2005. Saya Beragama Hindu. Jakarta: Media Hindu.

Nala, Ngurah I Gusti. (editor). 1995. Moksartahm Jagaditha. Jakarta: Upada Sastra.

Poerwanto, Hari. 2000. Kebudayaan dan Lingkungan Dalam Perspektif Antropologi. Yogyakarta: Pustaka Pelajar. 
Puja, G., Tjokorda Rai Sudartha. 2004. Atharwaweda. Surabaya: Paramitha.

Ritzer, Georga. 2003. Sosiologi Ilmu Pengetahuan Berparadigma Ganda. Cetakan IV. Jakarta: PT . Raja Grafindo Persada.

Salim, Emil. 1986. Pembangunan Berwawasan Lingkungan. Lembaga Penelitian. Pendidikan dan Penerangan Ekonomi dan Sosial (LP3ES).Cetakan I. Jakarta: LP3ES.

Soemarwoto, Otto. 1989. Ekologi Lingkungan Hidup dan Pembangunan. Bandung: Jambatan.

Sumaatmadja, H. Nursid.1998. Manusia Dalam Konteks Sosial, Budaya dan Lingkunan. Bandung: CV. Alfabeta.

Suastika, I Wayan. 2005. Tri Hita Karana, Antara Konsep dan Realita. Denpasar: Majalah Hindu Raditya.

Titib, I Made. 1996. Veda Sabda Suci, Pedoman Praktis Kehidupan. Surabaya: Paramita.

Undang-Undang RI No. 23. 1997. Tentang Pengelolaan Lingkungan Hidup. Jakarta: Kantor Mentri Negara Pengawasan Pembangunan dan Lingkungan Hidup.

Wiana, I Ketut. 1995. Yajnya dan Bhakti Dari Sudut Pandang Hindu. Denpasar: Pustaka Manik Geni. 
Jurnal Widya Sastra Pendidikan Agama Hindu, Vol. 3, No. 22020

e-ISSN : 2656-7466, p-ISSN : 1907-9559 